\title{
Contribution à l'évaluation de l'aptitude des étudiants à interpréter les divers outils de cohésion dans le discours informatique écrit
}

\section{Mourad Boughedaoui}

\section{OpenEdition}

\section{Journals}

Édition électronique

URL : http://journals.openedition.org/asp/4364

DOI : $10.4000 /$ asp.4364

ISSN : 2108-6354

\section{Éditeur}

Groupe d'étude et de recherche en anglais de spécialité

Édition imprimée

Date de publication : 1 mars 1993

Pagination : 107-128

ISSN : 1246-8185

\section{Référence électronique}

Mourad Boughedaoui, « Contribution à l'évaluation de l'aptitude des étudiants à interpréter les divers outils de cohésion dans le discours informatique écrit », ASp [En ligne], 1 | 1993, mis en ligne le 25 avril 2014, consulté le 02 mai 2019. URL : http://journals.openedition.org/asp/4364 ; DOI : 10.4000/ asp.4364

Ce document a été généré automatiquement le 2 mai 2019.

Tous droits réservés 


\title{
Contribution à l'évaluation de l'aptitude des étudiants à interpréter les divers outils de cohésion dans le discours informatique écrit
}

\author{
Mourad Boughedaoui
}

\section{Introduction}

1 Partant du fait que toute unité de discours général ou spécifique se doit d'être caractérisée par des relations internes de cohésion et de cohérence entre les phrases qui la composent, nous avons essayé d'étudier à travers des textes informatiques les mécanismes d'organisation textuelle qui mettent en évidence ces relations: "The expression of the semantic unity of the text lies in the cohesion among the sentences of which it is composed » (Halliday \& Hasan 1976 : 293)

2 Parmi les mécanismes d'organisation textuelle, les procédés anaphoriques constituent un réseau de marqueurs dont la fonction principale est de créer des liens étroits entre les différentes séquences d'énoncés d'un texte. C'est à travers la compréhension de tels procédés que le lecteur peu entrainé est à même de développer des stratégies communicatives efficaces de lecture. Ils permettent au lecteur de sortir des limites trop étroites de la phrase pour entrer dans le domaine plus vaste du discours :

Once we accept the need to teach language as communication, we can obviously no longer think of language in terms only of sentences. We must consider the nature of discourse, and how best to teach it. (Widdowson 1979: 90)

3 L'étude des mécanismes d'organisation textuelle, très souvent passée sous silence par les grammairiens, constitue un moyen de développer des outils didactiques nécessaires à un enseignement dont l'objectif principal est de familiariser les étudiants avec l'écrit. 
4 L'objectif de notre travail de recherche a été dans un premier temps d'étudier les divers procédés de cohésion textuelle dans un corpus composé de textes informatiques et, dans un deuxième temps, d'élaborer un questionnaire en vue d'évaluer l'aptitude de nos élèves de $1^{\text {re }}$ et $3^{\mathrm{e}}$ années ingénieurs, à l'Institut national informatique (INI) d'Alger, à interpréter ces procédés.

\section{Le test}

5 Le test, élaboré sur trois pages, se compose de deux parties (A) et (B) avec un total de seize petits passages de lecture de plus d'une phrase afin de mettre en évidence les procédés de cohésion (voir annexe 1). Dans la partie (A), les étudiants se devaient de choisir entre l'article indéfini et l'article défini pour compléter les blancs. Dans la partie (B), ils devaient trouver les référents textuels des mots soulignés. L'objectif de cette partie était de faire retrouver par les étudiants l'information source qui servait à l'interprétation de chaque item.

\section{Les procédés anaphoriques}

6 On parle de relation anaphorique chaque fois que l'interprétation d'un quelconque élément de discours dépend étroitement de l'identification d'un autre élément de ce même discours :

On dit qu'un segment de discours est anaphorique lorsqu'il est nécessaire pour son interprétation de faire référence à un autre segment du même discours. (Ducrot \& Todorov 1972 : 294)

7 De cette façon, les processus anaphoriques sous-tendent la continuité sémantique qui existe entre une partie d'un texte et une autre :

The continuity that is provided by cohesion consists, in the most general terms, in expressing at each stage in the discourse the points of contact with what has gone before. (Halliday \& Hasan 1976 : 299)

8 L'interprétation d'un segment anaphorique exige des indications concernant le passage précédent avec lequel le segment est en relation. Cette notion d'environnement, grâce à laquelle les interprétations sémantiques des éléments linguistiques sont rendues possibles, est importante dans l'élucidation des processus anaphoriques. L'environnement peut être représenté par le contexte de la situation dans laquelle l'énoncé a été produit, auquel cas la référence est exophorique, c'est-à-dire extérieure au texte.

9 Sinon, la référence est endophorique, c'est-à-dire intérieure au texte. Dans ce cas, l'environnement est constitué par le contexte textuel précédent. Bien que la cohésion soit une relation sémantique entre des segments d'un même discours, elle est effectuée par l'utilisation d'unités lexicales et grammaticales.

10 Dans le cas de l'anaphore lexicale, les références textuelles sont réalisées par l'utilisation de noms qui reprennent le contexte verbal précédent. Dans celui de l'anaphore grammaticale, les relations sont effectuées d'une phrase à une autre en ayant recours à un nombre fini d'éléments grammaticaux. Quelques-uns d'entre eux (tels les pronoms relatifs) sont limités aux frontières de la phrase, alors que d'autres (tels les démonstratifs) étendent leur action sur des unités discursives plus longues. 

system.

Parmi les différents types d'anaphore lexicale :

- par forme répétée totalement (1) ou partiellement (2),

- par remplacement lexical (synonymie [3], mots génériques [4], nominalisation [5] ou reprise du contexte [6]), seule la (1) apparaît dans le test. En fait, ceci a été essentiellement dû au fait que les passages illustrant la cohésion lexicale étaient trop longs (plus de trois à quatre phrases) et ne pouvaient être pris en considération à cause des contraintes de temps (une heure pour tout le test) :

(1) [...] other demands can be calculated by means of a technique devised by Greenberg. In this technique, message arrivals are assumed to be Poisson.

(2) The Karlsruhe screen-based application support system includes a distinct editor [...] and display logic. This system also manages functions [...]

(3) There are many ways in which the designer can combine these components and a computer to make an on-line system. At first sight, this variety might confuse and frighten off a potential user [...]

(4) Basically a data transmission system consists of terminals, communications links, and a transmission control device. There are many ways in which the designer can combine these components and a computer to make an on-line

(5) This process is then applied recursively with the resulting subgoal until the empty clause is produced. If this recursion fails to produce the empty clause [...]

(6) Once a record is scrolled off the screen, its values are no longer accessible to the user and can be removed from the list. Although this feature requires more memory [...]

Le reste du test traite d'exemples d'anaphore grammaticale. Celle-ci est caractérisée par l'effet de cohésion dont sont capables un nombre fini d'items non lexicaux. Ces items ne peuvent avoir de signification en eux-mêmes ; ils ne peuvent l'acquérir qu'en étant mis en relation avec d'autres segments qui les précèdent dans le discours et qui jouent ainsi le rôle de source sémantique ». Ce sont en quelque sorte, selon Halliday et Hasan des " directives indicating that information is to be retrieved from elsewhere" (Halliday \& Hasan 1976 : 31) et, en agissant ainsi, établissent des relations au sein même du texte.

Dans leur ouvrage, R. Quirk et alii ont fait, dans la partie intitulée « textual recoverability ", une étude intéressante du concept de recherche d'information à l'intérieur du texte pour l'interprétation des anaphoriques :

Textual recoverability is best regarded as a special case of situational recoverability; i.e., the information given elsewhere in the text is, for the purpose of discourse, the explicit par of the situational knowledge which is available to addresser and addressee."(Quirk et al. 1985 : 862)

\section{4. Étude de quelques pro-formes anaphoriques du test}

Pour des raisons de simplicité, nous utiliserons le terme générique " pro-forme » au lieu du terme pronom pour faire référence aux termes utilisés comme anaphoriques. Dans le cadre de notre étude, nous distinguerons les catégories suivantes de pro-formes : les proformes de référence et co-référence, les pro-formes de substitution et les pro-formes «\# » pour les constructions elliptiques. 


\subsection{Référence et co-référence}

17 La première catégorie concerne les pro-formes qui demandent au lecteur de rechercher l'information en dehors du texte pour leur interprétation. Les pro-formes typiques à cette sous-catégorie sont les formes de première et deuxième personnes :

First and second person forms do not normally refer to the text at all; their referents are defined by the speech roles of speaker and hearer and hence they are normally interpreted exophorically by reference to the situation" (Halliday \& Hasan 1976 : 48).

Dans les textes de notre corpus, ces pro-formes se rencontrent essentiellement dans les introductions d'articles de recherche, en début de discours :

(1) To this effect, we will present the major [.....]. We will establish that nearly all microprocessors [...]

(2) Let us examine fig. 2. Several areas can be distinguished.

(3) Thus the age-old need for more storage capacity [...] is still with us.

(4) Our solution is to remind the user that...

19 Nous trouvons aussi des constructions passives dont le but essentiel est de permettre à l'auteur de «s'effacer » de son discours :

(5) Although this chapter might appear complex during a first reading, it is strongly recommended that...

(6) It will be shown later in this chapter that...

(7) It is assumed that the reader is familiar with the basics of graph theory.

Ces procédés d'effacement de l'auteur comprennent aussi l'utilisation de tournures spécifiques telles que " ce chapitre ", « cette section », etc.

(8) This paper describes the application of certain results...

(9) This article presents the minicycle algorithm for...

21 En ce qui concerne les pro-formes de deuxième personne, elles sont pratiquement inexistantes à la surface du texte. Par contre, la référence $\mathrm{au}(\mathrm{x})$ lecteur(s) est effectuée à travers des tournures impératives, passives, la pro-forme impersonnelle « one » ou alors le groupe nominal explicite « the reader (s)»:

(10) Assume that main storage is [...]. Suppose further that odd-numbered addresses

are $[\ldots]$

(11) It should noted that PO permission to connect [...]

(12) Finally, one can notice on fig.2 a large number of...

(13) The reader should bear these limitations in mind as we examine [...]

Pour ce qui est de la co-référence, le lecteur cherchera ailleurs dans le texte les « antécédents » nécessaires à l'interprétation des pro-formes. Ces pro-formes établissent ainsi des relations endophoriques et constituent des liens de cohésion qui renforcent la structure interne du texte.

Il existe deux types de relations endophoriques : celles qui exigent de la part du lecteur la recherche en amont de la pro-forme de sa source sémantique (anaphore) et celles qui renvoient le lecteur en aval de la pro-forme (cataphore). La cataphore étant principalement limitée aux confins de la phrase, nous n'étudierons que les cas d'anaphore. Il arrive que l'élément anaphorique se trouve dans la même phrase que son antécédent sémantique ou dans le contexte de phrases éloignées.

C'est ce dernier cas qui fait de l'anaphore un moyen efficace de cohésion et que nous étudierons de façon plus particulière : 
Since cohesive relations are not concerned with structure they may be found just as well within a sentence as between sentence [...]. Cohesive ties between sentences stand out more clearly because they are the only source of texture, whereas within the sentence there are the structural relations as well. (Halliday \& Hasan 1976 : 8-9) phrases:

(16) An on-line system is designed and installed to serve a particular application. Its components have to fit together and [...]

(nent de co-réference dont l'utilisation est importante est le démonstratif «this » Dans le discours scientifique et technique, caractérisé par son souci de clarté et d'absence d'ambiguïté, le pronom démonstratif fait référence uniquement à des segments du texte et en aucun cas à des éléments de la situation.

C'est cette caractéristique des démonstratifs qui fait qu'ils sont utilisés comme prédéterminants dans l'emploi anaphorique de groupes nominaux :

(17) The CPU uses 32-bit virtual addresses, allowing access to over four gigabytes of virtual address space. These addresses are called virtual [...]

Le terme de la répétition, dans ce cas "addresses ", est introduit par le démonstratif « these " pour renforcer l'effet de cohésion. Le démonstratif «this», utilisé comme proforme de co-référence, ajoute au système anaphorique de l'anglais une capacité supplémentaire à faire référence à des segments de discours dépassant les limites du groupe nominal, des phrases, séquences de phrases, voire des paragraphes. C'est ce qu'on appelle la référence étendue "extended reference » où l'interprétation du démonstratif exige des inférences pragmatiques plus importantes de la part du lecteur :

(18) The essential advantage of a single-bus system should also be clear; it is the architecture that requires the least bus area. On a chip, it saves space. This is the critical consideration today for the implementation of a microprocessor.

(19) Special hardware logic on the board collects $2 \times 8$ bit of data and forces one 16 bit transfer to the dualported RAM to enhance and optimize data throughput. This results in a maximum data for [...]

La deuxième et la troisième catégories de pro-formes concernent les effets de cohésion réalisés par les procédés de Substitution et d'Ellipse par lesquels le langage permet d'éviter la répétition d'unités linguistiques à l'intérieur du texte :

The fundamental relation between parts of a text forces the reader, when he encounters substitution or ellipsis, back into the text to look for a previous expression to substitute, in the case of substitution, or to provide, in the case of ellipsis. (Brown \& Yule 1983 : 193)

31 Contrairement à la co-référence qui est une relation au niveau sémantique, la substitution et l'ellipse sont des variantes d'un même type de relation de cohésion au 
niveau lexico-grammatical ou, comme les définit Halliday: "It is a relationship in the wording rather than directly in the meaning » (Halliday 1985 : 296).

\subsection{Substitution}

C'est le procédé par lequel un élément du discours est remplacé par un autre élément qui doit impérativement être de la même classe grammaticale que lui. Si, pour la coréférence, il y a identité de référence entre la pro-forme et son antécédent, au niveau de la substitution et de l'ellipse il n'y a pas identité de référence :

A substitute is a carrier of some information which differentiates the instance in which it occurs from the other instance to which it relates by cohesion (Halliday \& Hasan 1976 : 93)

Dans l'exemple ci-après :

The student cannot find his program. He must have lost it. Hence he has got to write another one.

La pro-forme « one » fait référence à un membre différent de la classe "programme ». La différence est souvent mise en évidence par la présence d'un élément de modification précédant ou suivant le substitut

(20) In a formal structure, this is clearly a conscious risk decision for the receiver. In an informal one, it is a more serious violation of [...]

(21) The compression produced by a static table of the same language type as the source file was almost at least as good as that produced by the dynamic Huffman table.

Le nom, le verbe et la proposition constituent les parties du discours qui sont touchées par la substitution. Par conséquent, il existe 3 types de procédés substitutionnels qui sont respectivement la substitution nominale, verbale et propositionnelle :

(22) The design should also show how easily the current system can absorb changes and whether some immediate ones are necessary to increase the system's enhanceability.

(23) If the map specifies byte offset, the behaviour depends on whether the transaction crosses a long word boundary. Il it does not, then the response is identical to that described above for DATI (B).

(24) A check is made to see if there is a valid restart parameter block. If so, a restart sequence is initiated.

\subsection{Ellipse}

C'est le procédé grâce auquel des éléments du discours peuvent être effacés du texte sans pour cela altérer la signification globale du message. Ces éléments sont restitués par le lecteur par référence à des segments du contexte précédent :

It is a principle of efficient communication that we do not give the reader more information than he needs. We prefer to omit rather than repeat certain kinds of information which the reader's common sense can readily supply from the surrounding text. This omission is called ellipsis. (Nuttal $1982: 92$ )

L'ellipse est donc caractérisée par une absence significative de marque formelle au niveau du texte. Les constructions elliptiques donnent souvent l'impression d'une syntaxe disloquée pour le lecteur non expérimenté, comme le montre l'exemple ci-dessous :

${ }^{*}$ The oldest symbol is at the bottom of the stack and the youngest at the top. 
L'étude de notre corpus a montré que l'ellipse du nom joue un rôle important dans les relations inter-phrastiques. L'ellipse verbale constitue, à un degré moindre, un moyen de liaison à l'intérieur et entre les phrases.

(25) When power is restored, the memory controller checks to see if the contents of memory have been preserved by the battery unit. If they have not, the controller will write the contents of the entire memory system with zeros.

(26) Two are associated with receiving from the terminal and two with writing to the terminal.

Les trois procédés, viz. la coréférence, la substitution et l'ellipse, que nous avons étudiés peuvent être utilisés en même temps dans une seule phrase. Une telle phrase ne pourra pas en elle-même exprimer toute l'information qu'elle est sensée véhiculer. Elle dépendra fortement du contexte immédiat et/ou éloigné pour son interprétation.

\section{Résultats du test}

Il était important pour nous, enseignants, de pouvoir évaluer l'aptitude de nos étudiants à interpréter de façon adéquate les outils lexico-grammaticaux de cohésion lors de la lecture de textes. Pour les besoins du traitement des données du test, nous avons représenté les trois types de pro-formes respectivement par CPF (co-referential pro-forms), SPF (substitutional pro-forms) and E (ellipsis). Le nombre d'élèves qui ont subi le test s'élevait à 228 répartis en 114 étudiants de $1^{\text {re }}$ année et 114 de $3^{\mathrm{e}}$ année.

\subsection{Analyse de la partie B}

40 Afin d'avoir un aperçu complet sur les résultats du test, nous avons comparé, pour chaque population d'étudiants, les trois catégories susmentionnées entre elles. Ensuite, pour mettre en évidence les différences et/ou les similitudes entre ces deux populations, nous avons procédé à la comparaison bilatérale de chaque catégorie.

Pour les élèves de $1^{\text {re }}$ année, l'étude statistique réalisée sur micro-ordinateur, grâce au logiciel LOTUS 123, a donné les indications suivantes (à noter que pour chaque comparaison, il y a un histogramme correspondant fourni en annexe 2) :

1. CPF1 vs E1 : taux élevé d'erreurs pour les CPF

2. SPF1 vs E1 : taux d'erreurs plus élevé pour les SPF

3. CPF1 vs SPF1: taux d'erreurs pour les SPF.

Concernant les élèves de 3e année, nous avons :

1. CPF3 vs E3 : taux d'erreurs élevé pour les CPF

2. SPF3 vs E3 : taux d'erreurs plus élevé pour les SPF

3. CPF3 vs SPF3 : taux d'erreurs légèrement plus élevé pour les SPF.

Les comparaisons bilatérales entre les mêmes types de pro-formes font ressortir que :

1. pour E1 vs E3 : les élèves de 1re année font plus d'erreurs d'interprétation.

2. pour CPF1 vs CPF3: les élèves des deux populations ont un comportement identique concernant cette catégorie.

3. pour SPF1 vs SPF3: les élèves de 1re année font plus d'erreurs dans cette catégorie.

En conclusion, nous remarquons un meilleur comportement de la part des étudiants de $3^{\mathrm{e}}$ année quant à la manipulation des outils de cohésion textuelle. Ceci peut s'expliquer par le fait que durant les deux premières années de leur programme du cours d'anglais un intérêt important est réservé à la pratique de l'expression et de la compréhension écrites. 
Il y a aussi le fait que les élèves de $3^{\text {e }}$ année avaient déjà une connaissance du vocabulaire informatique qui a sûrement gêné les étudiants de $1^{\text {re }}$ année, qui arrivaient du lycée.

Parmi les pro-formes de co-référence ( $\mathrm{CPF}$ ) qui ont posé des difficultés d'interprétation, on a le démonstratif «this », le pronom neutre «it » et le pronom relatif "phrastique » ( sentential relative pronoun). De façon générale, les pro-formes qui réfèrent à des segments des phrases ou des segments de discours plus longs sont difficiles à manipuler par les étudiants. En vue de familiariser les élèves à ces outils de cohésion, il serait intéressant de développer des exercices appropriés axés sur la mise en évidence du champ d'action de telles pro-formes et de leur importance en tant qu'éléments du réseau complexe de la cohésion et la cohérence sur lequel se base l'unité sémantique du texte.

Comme nous l'avons vu, l'interprétation des pro-formes de substitution (SPF) a constitué un réel problème pour les deux populations d'étudiants. Parmi celles qui ont connu un taux élevé d'erreurs, nous avons le pro-verbe «do », le pronom démonstratif «that », le pro-complément « the same » et le pronom indéfini « one ».

Concernant enfin l'ellipse, les élèves de $1^{\text {re }}$ année ont eu des difficultés avec les constructions elliptiques nominales "these \# ", " the next \# ", " the most obvious \# " et l'ellipse verbale « will\#» (voir annexe 1).

Compte tenu de certaines difficultés causées par les constructions elliptiques, les étudiants ont besoin d'être familiarisés avec les modèles structuraux de l'ellipse. L'acquisition des procédés elliptiques constitue un atout non négligeable en vue de développer une lecture efficace. Là aussi, en créant des exercices centrés sur les aspects de reconnaissance, d'interprétation et aussi de production de constructions elliptiques, l'enseignant aidera ses élèves à appréhender avec un maximum d'efficacité de telles structures.

\subsection{Analyse de la partie $A$}

La règle générale à appliquer dans cette partie concerne uniquement les unités lexicales qui sont indéfinies lors de leur première apparition dans un discours et définies lorsqu'elles sont réutilisées dans ce même discours. Dans ce cas, elles sont précédées de l'article défini « the » en tant que déterminant anaphorique.

L'analyse statistique de cette partie a donné les résultats suivants (avec leurs histogrammes respectifs en annexe 3 ) : les élèves de $3^{e}$ année ont eu un taux plus élevé de succès.

49 Au niveau de la cohésion, l'article défini est utilisé comme un marqueur de la deuxième mention. Là où il est possible d'avoir un pronom pour la deuxième mention d'un nom, le langage technique et scientifique préfère la répétition du premier mot précédé de l'article défini. Ceci rend bien sûr la compréhension plus facile.

Le bon comportement des étudiants dans cette partie du test est sûrement dû au fait que ce phénomène est le même dans les deux langues qu'utilisent nos élèves, l'arabe et le français.

51 Effectivement, la structure «le $+\mathrm{N}$ », «la $+\mathrm{N}$ » a une valeur anaphorique quand elle reprend un terme du discours introduit par la structure « un $+\mathrm{N}$ », « une + N ». Du fait de son rôle cohésif, il est intéressant dans notre enseignement de mettre l'accent sur l'alternance « $a /$ the » et la relation anaphorique qu'elle établit au sein du texte et de concevoir et produire des exercices appropriés. 


\section{Conclusion} étaient susceptibles de gêner voire fausser la compréhension des procédés de cohésion entre les phrases d'unités textuelles. Concernant ces procédés, nous avons insisté sur le besoin des apprenants de maîtriser les outils lexico-grammaticaux qui sous-tendent les relations anaphoriques.

Qu'ils soient co-référentiels, substitutionnels ou elliptiques, ces mécanismes, afin d'être correctement interprétés, demandent de la part du lecteur une recherche d'informations à travers les différentes parties du texte. Les étudiants, étant essentiellement entraînés à travailler au niveau de la phrase, ignorent pour la plupart la façon dont sont utilisés les moyens linguistiques pour établir des connexions de phrase à phrase et de paragraphe à paragraphe. Pour cette raison, ils ont besoin d'être initiés et entraînés à opérer non seulement au niveau de la phrase, mais aussi et surtout au niveau d'unités discursives plus importantes afin de développer réellement des aptitudes à appréhender l'écrit. L'objectif de l'enseignant serait par conséquent de fournir le matériau linguistique qui renforcera et encouragera cette pratique tant nécessaire au scientifique qu'est la lecture.

\section{BIBLIOGRAPHIE}

Brown, G. et Yule, G. 1983. Discourse Analysis. Cambridge : Cambridge University Press.

Ducrot, O. et T. Todorov. 1972. Dictionnaire Encyclopédique des sciences du langage. Paris : Seuil.

Halliday, M.A.K. et R. Hasan. 1976. Cohesion in English. Londres : Longman.

Halliday, M.A.K. 1985. An Introduction to Functional Grammar. Londres : Edward Arnold Publishers.

Nuttal, C. 1982. Teaching Reading Skills in a Foreign Language. Londres : Heinemann Educational Books.

Guirk, R. S. Greenbaum, G. Leech et J. Svartvik. 1985. A Comprehensive Grammar of the English Language. Londres : Longman.

Widdowson, H.G. 1979. Explorations in Applied Linguistics. Oxford : Oxford University Press.

\section{ANNEXES}

\section{Annexe 1. Test soumis aux élèves de $1^{\text {re }}$ et $3^{e}$ années INI}

This test is part of a research project which aims at assessing the students' ability to cope with cohesive devices when reading texts.

\section{A. Fill in the blanks with either "a/an" or "the":}

a. The VAX-11/730 processor contains .1. interval timer and .2. time-of-year clock. .3. 
interval timer permits the measurement of finely resolved intervals. .4. time-of-year clock is used by software to perform various timekeeping functions.

b. The TIB 0303is .5. single-chip bubble memory in .6. dual-in-line package. .7. package includes. .8. chip, two permanent magnets, two coils, and .9. magnetic shield. .10. two permanent magnets allow for the stable existence of magnetic bubble domains on .11. chip and provide non-volatility when the power is off.

\section{B. What do the underlined words refer to?}

1. The lines appear to occupy a relatively large area of the chip. This is an inactive area of the chip, which cannot be used to implement logical functions.

Which:

2. Whenever two 2 's-complement numbers are added, the carry generated during an addition or subtraction might overflow into the sign bit. When it does, it might change a negative number into a positive number.

It:

Does:

3. Clauses $\mathrm{Q} 1-\mathrm{Q} 4$ together state that either $\mathrm{X} 1$ is a working ' $\mathrm{XOR}$ ' gate or the other devices are OK. Clauses Q1 and Q5-Q7 state, the same for X2, and so forth.

The same:

4. A check is made to see if there is a Valid Restart Parameter Block

(RPB). If so, a restart sequence is initiated.

So:

5. The console subsystem starts at address zero and searches all available memory for a valid RPB. If it doesn't find one it performs the second action specified by the power on switch (HALT or BOOT).

It:

One:

6. If the map specifies byte offset, the behaviour depends on whether the transaction crosses a long word boundary. If it does not, then the response is identical to that described above for DATI (P).

Does not:

That:

7.Many companies in the United Kingdom are successfully using on-line systems. Some, even if they took the initial decision with apprehension and encountered unexpected difficulties along the way, are very satisfied with the benefits.

Some:

They:

8. It is possible to identify a number of situations which could make use of on-line systems. Readers are invited to think of others.

Others:

9. The VAX-11/750 console runs in three modes: program I/O mode, console mode, and RDM console mode. These are mutually exclusive. One of the three will always be enabled while there is power to the machine.

These:

The three: 
10. All five of these mechanisms will initiate the following sequence of actions. The first two will not perform the first step listed. This implies that the first two will cause a boot independent of the state of the cold start bit, while the last three will not.

The first two:

This:

The last three:

Will not:

11.In addition, the control store contains an 80-bit buffer, enabling it to execute one microword while simultaneously fetching the next.

It:

The next:

12. Dennis and Schnabel have given a set of test problems for use with packages. The first three of these are used here to illustrate the S-algol implementation, with and without the use of ALGLIB.

These:

13. The use of logic programming in this application area has several important advantages. The most obvious is that a single design description can be used for multiple purposes.

The most obvious:

14. The carry is used as a spill-out during the shift and rotate operations. When used as such, the carry behaves again as a ninth bit of the register, which justifies the merging of these two functions into the same bit.

Such:

Which:

\section{RÉSUMÉS}

À partir d'une étude des divers procédés de cohésion textuelle dans un corpus de textes informatiques, un questionnaire a été élaboré afin d'évaluer l'aptitude des étudiants à interpréter ces procédés. Le test consistait en une série de passages de lecture courts dont le traitement informatique a permis d'avoir un aperçu sur les types de difficultés posées par l'interprétation des outils lexico-grammaticaux sous-tendant les relations anaphoriques au sein des textes.

Following a survey of the various textual processes of cohesion in a collection of computer science texts: a questionnaire was devised to assess the students' ability to interpret these processes. The questionnaire consisted in a series of short reading passages the process of which has given insight into the types of difficulties that arose during the interpretation of the lexicogrammatical devices underlying the anaphoric relations within the texts.

INDEX

Mots-clés : cohésion, discours, informatique, organisation, évaluation

Keywords : computer science, discourse 


\section{AUTEUR}

MOURAD BOUGHEDAOUI

IUT de Paris. bougheda@iut.univ-paris5.fr 